\title{
Pelatihan terstruktur: usaha peningkatan kompetensi guru dalam penulisan artikel jurnal ilmiah
}

\author{
Afrianto Daud ${ }^{*}$, Ando Fahda Aulia, Nita Rimayanti, \& Mirza Hardian \\ Universitas Riau \\ * afrianto.a@lecturer.unri.ac.id
}

\begin{abstract}
Abstrak. Kemampuan menulis pada jurnal ilmiah adalah termasuk diantara bagian kompetensi profesional seorang guru. Masalahnya adalah bahwa banyak guru belum menguasai keterampilan menulis karya ilmiah ini. Akibatnya banyak guru kesulitan naik pangkat, terutama untuk naik pangkat setelah IV/a. Tulisan ini memaparkan satu kegiatan pengabdian masyarakat yang ditaja oleh dosen Universitas Riau yang bertujuan membantu guru dalam meningkatkan kemampuan menulis ilmiah mereka. Kegiatan pengabdian dilaksanakan di satu sekolah di Pekanbaru, Riau. Tulisan ini lebih jauh menjelaskan konsep pelatihan, konten materi pelatihan, dan efektivitas pelatihan. Pelatihan ini berlangsung selama dua bulan dengan tiga kali pelatihan tatap muka. Selebihnya dilakukan dilakukan secara daring melalui platform Google Classroom. Konten materi mencakup prinsip dasar penulisan ilmiah, langkah-langkah menulis jurnal ilmiah, cara mensitasi dan membuat referensi sesuai kaidah ilmiah, termasuk bagaimana mensitasi secara otomatis dengan menggunakan aplikasi reference manager seperti Mendeley, dan bagaimana mensubmit artikel melalui sistem OJS jurnal secara online. Data dari survey yang dilakukan pada sesi akhir kegiatan pengabdian menunjukkan bahwa secara umum kegiatan ini sudah berjalan baik dan efektif. Mayoritas peserta $(72,7 \%)$ menyatakan bahwa motivasi menulis mereka meningkat setelah mengikuti pelatihan. Pengetahuan mereka menjadi lebih baik setelah pelatihan. Kemampuan mereka dalam menulis jurnal ilmiah juga relatif lebih baik dibanding sebelum mengikuti pelatihan terstruktur ini.
\end{abstract}

Kata kunci: penulisan ilmiah, artikel jurnal, profesionalisme guru, keterampilan menulis

Abstract. The ability to publish articles in scientific journals is among the parts of a teacher's professional competence. The problem is that many teachers have not mastered the skills to write scientific papers. As a result, many teachers find it difficult to advance in rank, especially for promotion after IV / a. This paper describes a community service activity sponsored by Universitas Riau lecturers which aims to help teachers improve their scientific writing skills. Community service activities were carried out at a school in Pekanbaru, Riau. This paper further explains the concept of the workshop, the content of workshop materials, and the workshop's effectiveness. This workshop lasted for two months with three face-to-face training. The rest was done online via the Google Classroom platform. The material content covers the basic principles of scientific writing, the steps for writing scientific journals, how to cite and make references, including how to automatically cite using reference manager applications such as Mendeley, and how to submit articles through the online journal OJS system. Data from the survey conducted at the end of the community service activity showed that, in general, this activity was running well and effectively. The majority of participants $(72.7 \%)$ stated that their motivation to write increased after attending the training. Their knowledge of writing scientific articles have improved after training. Their ability in writing scientific journals is also relatively better than before following this structured workshop.

Keywords: scientific writing, journal article, teachers profesionalisme, writing skills

To cite this article: Daud, A., A. F. Aulia., N. Rimayanti., \& M. Hardian. 2020. Pelatihan terstruktur: usaha peningkatan kompetensi guru dalam penulisan artikel jurnal ilmiah. Unri Conference Series: Community Engagement 2: 90-97. https://doi.org/10.31258/unricsce.2.90-97

(C) 2020 Authors

Peer-review under responsibility of the organizing committee of Seminar Nasional Pemberdayaan Masyarakat 2020 


\section{PENDAHULUAN}

Guru adalah kunci dan pemain utama dalam menjalankan proses pendidikan. Konten kurikulum yang sempurna, fasilitas atau infrastruktur pendidikan yang lengkap, aturan main atau perangkat hukum yang canggih tidak akan banyak memberi pengaruh terhadap keberhasilan pendidikan jika tidak ditopang oleh kesiapan para guru di lapangan (Palmer, 1999). Karena alasan ini, adalah tepat jika pemerintah Indonesia memberikan perhatian khusus terhadap usaha profesionalisasi pendidik dalam sepuluh tahun terakhir, terutama setelah berlakunya UU 14/2005 tentang guru dan dosen. Menjadi guru profesional kemudian menjadi isu penting semua stakeholders pendidikan Indonesia setelah itu.

Salah satu upaya yang perlu dilakukan dalam rangka meningkatkan profesionalisme guru adalah gerakan menulis karya ilmiah. Hal ini sejalan dengan Undang-Undang Republik Indonesia No. 14 tahun 2005 tentang Guru dan Dosen, pasal 20 bagian b, yang menyatakan bahwa dalam melaksanakan tugas keprofesionalannya, guru berkewajiban untuk meningkatkan dan mengembangkan kualifikasi akademik dan kompetensi secara berkelanjutan sejalan dengan perkembangan ilmu pengetahuan, teknologi, dan seni, sehingga kemampuan menulis karya ilmiah sangat penting untuk menunjang profesionalisme sebagai guru.

Guru yang tidak mampu menulis akan mengalami kendala berkomunikasi karena dalam melaksanakan tugas sehari-hari seorang guru dituntut mampu menulis, seperti menulis surat dinas, menulis laporan kegiatan, dan menulis karya ilmiah untuk kenaikan pangkat (Keraf, 1996). Pada dasarnya keterampilan menulis karya ilmiah merupakan sebuah kemampuan mutlak yang harus dikuasai oleh guru, terutama untuk pengembangan keprofesionalan dalam melaksanakan tugas seperti kemampuan guru dalam menulis karya ilmiah dan menerbitkannya di jurnal ilmiah adalah salah satu upaya untuk mendapatkan angka kredit yang dapat dipergunakan dalam persyaratan peningkatan karir atau kenaikan pangkat.

Namun demikian kenyataan menunjukkan bahwa banyak guru yang mengalami kendala untuk naik pangkat golongan IVa ke jenjang golongan IVb yang disyaratkan harus mempunyai karya ilmiah. Aturan terbaru tentang kenaikan pangkat guru (Permenpan No. 16/2009) bahkan mewajibkan para guru memiliki angka kredit bidang penulisan dan publikasi ilmiah sejak kenaikan pangkat dari III B ke III C.

Permasalahan yang dihadapi guru adalah kurangnya motivasi untuk menulis karya ilmiah dan minimnya pengetahuan aspek-aspek teknik menulis karya ilmiah. Hal ini didukung kesibukan guru dan tidak adanya waktu luang untuk menulis karya ilmiah. Kurangnya motivasi untuk menulis dan minimnya pengetahuan aspek teknik menulis karya ilmiah secara benar menyebabkan banyak di Kota Pekanbaru yang kenaikan pangkatnya terhenti pada golongan IV a (Daud, 2007). Oleh karena itu kegiatan menulis karya ilmiah bagi guru harus terus dibudayakan.

Fenemona rendahnya kemampuan guru-guru SMP dan SMA dalam menulis karya ilmiah sepertinya terjadi di banyak tempat, termasuk di Kota Pekanbaru. Beberapa kajian yang dilakukan oleh peneliti lain, seperti studi oleh Bunyamin (Bunyamin, 2016)yang mengukur tingkat kompetensi guru di Jakarta menunjukkan bahwa tingkat kemampuan guru dalam menulis karya ilmiah masih rendah. Studi yang mirip dilakukan oleh Marwan (2017) terhadap guru Bahasa Inggris di Pontianak. Hasilnya menunjukkan bahwa mayoritas guru kesulitan untuk bisa publish di jurnal nasional terakreditasi.

Beberapa permasalahan yang dapat diidentifikasi berkaitan dengan rendahnya kemampuan guru-guru menulis artikel ilmiah dapat diuraikan sebagai berikut. Pertama, guru-guru SMP dan SMA kurang memiliki sumber-sumber informasi, seperti buku dan jurnal. Kedua, guru-guru SMP dan SMA umumnya tidak memiliki hasil penelitian atau gagasan untuk ditulis. Hal ini sangat berkaitan dengan masalah pertama, yaitu kurang tersedianya sumber informasi berupa buku dan jurnal tentang pendidikan serta supervisi yang dilakukan oleh Kepala Sekolah untuk mewujudkan upaya perbaikan dan pengembangan kualitas proses pembelajaran dan sekolah sebagai sebuah sistem. Ketiga, kemampuan guru-guru SMP dan SMA dalam menulis atau menuangkan ide dalam tulisan secara umum masih sangat rendah. Guru-guru SMP dan SMA umumnya tidak terbiasa menulis. Terakhir, kendala yang dihadapi oleh guru-guru SMP dan SMA yaitu kurang memahami aturan tata tulis ilmiah dalam aturan penulisan jurnal ilmiah.

Di samping itu, tulisan yang dibuat oleh guru-guru SMP dan SMA keterkaitan antar paragraf masih kurang yang disebabkan oleh kebiasaan dalam menulis secara tersistematis. Sementara itu pada bagian metode penelitian, desain penelitian tidak mencerminkan aturan yang sesuai untuk melakukan penelitian. Pada bagian hasil dan pembahasan tidak menyajikan hasil secara ringkas yang umumnya tidak menampilkan standar deviasi. Disisi lain kendala yang ditemukan adanya penyajian data yang sama disajikan dalam berbagai bentuk. Hal ini berarti bahwa data sudah disajikan dalam bentuk tabel, juga disajikan dalam bentuk grafik. Pada bagian pembahasan sering ditemukan pembahasan hasil temuan penelitian tidak dianalisis secara mendalam, 
melainkan menarasikan temuan atau hasil secara panjang lebar. Demikian juga guru-guru kurang membandingkan temuannya dengan temuan lain yang dihasilkan oleh peneliti lain. Kondisi di atas akan menjadikan guru-guru SMP dan SMA sebagai konsumen ide, bukan sebagai produsen ide.

Guru-guru SMP dan SMA hendaknya dapat menghasilkan ide-ide atau gagasan inovatif yang dapat disebarluaskan kepada sesama profesi sebagai sumber referensi terbaru. Jika setiap orang guru SMP dan SMA dapat menghasilkan ide-ide inovatif dan membaginya kepada guru-guru SMP dan SMA lain, maka ide-ide tersebut akan dapat dimiliki oleh guru-guru lain. Dengan kata lain, proses berbagi (memberi dan menerima) akan dapat berlangsung secara berkelanjutan. Inilah yang sesungguhnya disebut sebagai masyarakat ilmiah dan masyarakat belajar (learning community). Luaran yang diharapkan dari kegiatan PKM ini adalah artikel ilmiah yang siap dipublikasikan dalam jurnal ilmiah dan berdirinya minimal satu jurnal ilmiah yang dikelola secara mandiri oleh guru SMP dan SMA di Pekanbaru.

Karya ilmiah dapat digolongkan menjadi 2 (dua), yaitu (a) karya ilmiah laporan hasil penelitian, dan (b) karya ilmiah tinjauan ilmiah. Karya ilmiah tersebut dapat disajikan dalam bentuk buku, diktat, modul, karya terjemahan, makalah, tulisan di jurnal, maupun artikel di media massa. Karya ilmiah juga berbeda macamnya, yaitu: (a) penelitian, (b) karangan ilmiah, (c) ilmiah popular, (d) prasaran seminar, (e) buku, (f) diktat, dan (g) terjemahan (Eko Putro Widoyoko, 2008).

Setiap karya ilmiah harus mengandung kebenaran ilmiah, yaitu kebenaran yang tidak hanya didasarkan rasio, tetapi juga dapat dibuktikan secara empiris(Nana Sudjana, 1987). Rasionalisme mengandalkan rasio atau penalaran, sedangkan empirisme mengandalkan bukti atau fakta. Berpikir secara ilmiah berarti menggabungkan cara berpikir rasional dan empiris. Operasionalisasi berpikir ilmiah disebut penelitian ilmiah, sedangkan hasil penerapan metode ilmiah disebut karya ilmiah. Dengan demikian tidak semua karya tulis dapat disebut sebagai karya ilmiah.

Zemach and Rumisek (2005) mengemukakan bahwa proses menulis karya ilmiah dilakukan dalam beberapa tahapan, yaitu: (a) tahap prapenulisan, termasuk melakukan brainstorming dan membuat outline, (b) tahap penulisan, dan (c) tahap revisi. Tahap prapenulisan adalah tahap perencanaan atau persiapan, meliputi: penentuan topik atau masalah tulisan, pengumpulan bahan tulisan, dan penyusunan kerangka karangan. Tahap penulisan adalah pengembangan kerangka karangan menjadi karangan utuh dengan membahas setiap ide pokok pada kerangka karangan. Tahap revisi adalah perbaikan, tidak hanya dilakukan terhadap aspek isi dan sistematika tulisan, tetapi juga gramatika dan ejaan. Revisi tidak hanya dilakukan oleh penulis terhadap tulisannya sendiri, tetapi juga dapat dilakukan berdasarkan masukan orang lain atau reviewer.

Dengan demikian, rumusan permasalahan yang akan dicari jawabannya adalah sebagai berikut. 1) Bagaimana meningkatkan kemampuan guru dalam menulis dan publikasi karya ilmiyah? 2) Keterampilan apa saja yang diperlukan guru-guru SMP dan SMA di Kota Pekanbaru untuk menulis dan mempublikasi karya ilmiah?

\section{METODE}

Untuk menjawab masalah yang disebutkan di atas, kami melakukan kegiatan pengabdian kepada masyarakat melalui beberapa metode. Pertama, seri Workshop Terstruktur. Karena distancing dan tutupnya proses belajar mengajar akibat Covid, workshop dilaksanakan antara kombinasi daring dan luring. Berlangsung selama 2 bulan (Agustus - September 2020).

Kegiatan wokshop diawali dengan memberikan panduan untuk mengakses berbagai sumber referensi gratis yang mudah untuk digunakan yang dilanjutkan dengan melakukan penyegaran terhadap urgensi dalam melakukan penelitian dan publikasi hasil penelitian untuk guru. Kegiatan workshop akan dilakukan sebanyak tiga kali. Pada sesi pertama, workshop berupa pemaparan tentang gambaran penelitian yang memungkinkan untuk dilaksanakan di lingkungan sekolah serta dipandu dalam menentukan rumusan masalah, menemukan sumber referensi yang relevan, dan metode penelitian yang sesuai dengan rumusan masalah dengan target capaian berupa tersedianya desain penelitian oleh masing-masing guru.

Sesi kedua workshop guru dilatih menggunakan aplikasi Mendeley dalam membuat sitasi dan referensi otomatis. Mendeley adalah aplikasi untuk mengelola referensi (reference manager) yang bisa digunakan secara gratis. Aplikasi ini sangat membantu seorang penulis dalam mencari, menyimpan, dan mengintegrasikan referensi menjadi kutipan dan daftar pustaka dalam tulisan. Dengan menggunakan aplikasi semua proses pengutipan bisa dilakukan secara otomatis tanpa perlu menghapal aturan-aturan detail untuk setiap jenis gaya referensi, seperti APAth, Harvard, IEEE, dan lainnya. 
Pada sesi ketiga, workshop berupa pemberian umpan balik terhadap drat manuskrip yang sudah dihasilkan guru. Umpan balik dilakukan secara daring melalui Google Classroom dan juga ketika pertemuan di darat. Pada sesi terakhir ini, peserta juga dilatih bagaimana mensubmit artikel ke jurnal nasional terakreditasi. Diantara target luaran pelatihan ini adalah terdapat minimal satu tulisan guru yang bisa terbit di jurnal nasional terakreditasi dengan berkolaborasi dengan dosen.

Metode kedua adalah pendampingan.Kegiatan pendampingan dilaksanakan di dalam kelas yang dikombinasikan dengan menggunakan aplikasi google classrom dengan tujuan untuk memberikan tutorial dan supervisi untuk membantu guru pada proses sebelum merancang penulisan artikel ilmiah sampai pada tahap publikasi. Kegiatan pendampingan juga melibatkan mahasiswa Kukerta Universitas Riau yang tergabung dalam kegiatan pengabdian ini. Ketiga, survey persepsi. Survey dilakukan untuk mengukur efektivitas dan feedback guru terhadap workshop. Survey ini dilakukan dalam bentuk pengisian kuesioner yang terdiri dari beberapa pertanyaan tertutup dan terbuka (lihat lampiran). Efektivitas program dianalisa dengan membandingkan jawaban peserta sebelum pelatihan dan setelah pelatihan.

\section{HASIL DAN KETERCAPAIAN}

Membuat tulisan ilmiah memang adalah kegiatan yang tak mudah. Kemampuan ini memerlukan beberapa skills yang cukup kompleks. Mulai dari memahami konten yang akan ditulis, memiliki kemampuan bahasa tulis yang baik, sampai memahami teknis kepenulisan ilmiah yang sering ribet dan rigid. Ini belum lagi bicara tentang seluk beluk proses penerbitan, mulai dari mengetahui hal teknis mensubmit tulisan ke sistem jurnal yang dituju sampai memahami jenis dan kualitas jurnal yang dituju.

Kerumitan seperti inilah diantara yang menjadi alasan mengapa menulis publikasi ilmiah menjadi momok bagi sebagian guru. Sebagian mereka memilih tidak mengurus naik pangkat dalam waktu yang cukup lama ketimbang menghabiskan waktu untuk sesuatu yang tidak langsung ada dampaknya kepada mereka. Sebagian mereka bahkan telah menyerah sebelum mencoba. Wajar kemudian banyak guru yang stagnan di level pangkat tertentu, terutama guru PNS.

Pelatihan dengan materi terstruktur kemudian menjadi relevan untuk dilaksanakan. Pelatihan yang kami laksanakan selama kurun waktu dua bulan ini adalah di antara usaha kami membantu guru mencarikan jalan keluar dari kerumitan proses penulisan jurnal ilmiah. Sebagai sebuah kegiatan pelatihan terstruktur, kami merancang kegiatan pada tiga fokus kegiatan menulis jurnal: kegiatan sebelum menulis, ketika menulis, dan pascamenulis (submit) artikel ke jurnal yang dituju.

\section{Fase Merencanakan}

Secara lebih rinci, pada kegiatan pre-writing guru dilatih merencanakan artikel mereka. Merencanakan apa yang hendak ditulis merupakan awal dari segalanya. Jika seorang penulis gagal berencana, maka itu sama saja dengan merencanakan untuk gagal dalam menulis. Banyak tulisan yang ditolak oleh jurnal karena kurang baiknya perencanaan. Berikut adalah beberapa perencanaan yang harus dilakukan sebelum memulai menulis sebuah artikel ilmiah. Pertama, menentukan jenis tulisan. Seorang penulis hendaknya berpikir sejenak mengenai jenis tulisan apakah yang akan dibuat. Apakah artikel itu merupakan research report atau nonresearch article, atau hanya literature review. Kedua, menentukan topik tulisan. Topik tulisan merupakan inti dari apa yang berusaha kita sampaikan dalam sebuah artikel jurnal. Pilihlah topik yang sesuai dengan keahlian, topik yang sedang banyak dibahas, atau topik yang sesuai dengan bisa jurnal yang dituju. Ketiga, temukan 'pancingan' (hook) untuk menarik minat pembaca. Di dalam menulis artikel ilmiah, sebuah 'hook' adalah hal yang patut dipertimbangkan. Pasalnya, pancingan tersebut akan menaikkan rating pembaca dan juga akan menaikkan branding kita sebagai seorang penulis artikel ilmiah. Keempat, pikirkan aspek ketertarikan jurnal. Sejak awal perlu diajukan pertanyaan "Apakah jurnal akan tertarik untuk menerima artikel saya?” Dalam hal ini, seorang penulis perlu mempelajari ruang lingkup jurnal yang akan dituju, termasuk aturan-aturan spesifik sebuah jurnal. Bagian akan kami bahas pada poin di bawah.

Setelah merencanakan, para guru juga diajarkan bagaimana memilih jurnal yang akan dituju. Saat ini ada banyak jenis jurnal yang dapat dipilih sesuai dengan topik tulisan. Umumnya, terdapat 4 jenis jurnal, diantaranya adalah: 1) Jurnal dengan topik spesifik versus topik umum. Terdapat jurnal yang menerbitkan artikel-artikel dengan topik sangat spesifik, jurnal pendidikan anak usia dini, jurnal ilmu tanah,jurnal gigi dan mulut. Tetapi, ada juga jurnal yang menerbitkan topik secara umum saja, seperti jurnal ilmu pendidikan; 2) Jenis riset (qualitative vs quantitative). Ada jurnal yang hanya menerima tulisan riset kualitatif, atau ada jurnal yang hanya menerima riset kuantitatif saja. Ada juga jurnal yang menerima keduanya. Seorang penulis perlu mengetahui kecenderungan jurnal yang akan dia tuju; 3) High impact vs low impact. Jurnal juga mempunyai 
tingkat kepopuleran masing-masing. Jika suatu jurnal banyak dikutip oleh penulis lain dalam menulis artikel ilmiah mereka, maka jurnal tersebut dikategorikan sebagai jurnal 'high impact'. Begitu juga sebaliknya, jika jurnal tersebut sedikit dikutip oleh khalayak, maka jurnal tersebut termasuk ke dalam jurnal low impact. Jurnal dengan high impact memiliki aturan yang ketat dalam penerbitannya. Tak heran, jika kredibilitas dari artikel yang sudah diterbitkan disini merupakan artikel yang 'bergengsi'. Poin penting lain yang perlu diingat pada fase ini adalah berusaha mengetahui kredibilitas sebuah jurnal. Perlu diketahui bahwa tidak semua jurnal yang mempunyai kredibilitas yang baik. Terdapat juga jurnal yang dapat menipu para penulis artikel ilmiah. Untuk menyiasati hal tersebut, hendaklah seorang penulis mengetahui hal-hal dasar mengenai jurnal ilmiah nasional dan internasional.

Secara umum jurnal terbagi dua: jurnal nasional dan jurnal internasional. Jurnal nasional pun terbagi dua lagi: jurnal nasional terakreditasi dan jurnal nasional tidak terakreditas. Terdapat beberapa syarat agar sebuah jurnal bisa terakreditasi. Diantaranya jurnal tersebut harus diterbitkan oleh lembaga atau organisasi profesi ilmiah atau kerjasama organisasi profesi ilmiah dengan perguruan tinggi ataupun lembaga lainnya; jurnal ilmiah harus memiliki mitra bebestari yang berasal dari berbagai institusi; jurnal harus memiliki e-ISSN dan sejumlah syarat lainnya. Jurnal nasional yang sudah terakreditasi dilevelisasi menjadi 6 tingkat: Sinta 1 - Sinta d (S1-S6). Daftar jurnal yang sudah terakreditasi bisa dilihat di www.sinta.ristekbrin.go.id.

Sementara jurnal internasional juga terbagi dua: jurnal internasional bereputasi dan jurnal internasional belum bereputasi. Reputasi sebuah jurnal internasional diantaranya ditandai oleh jumlah sitasi penulis lain pada artikel jurnal tersebut. Jurnal yang bereputasi internasional biasanya adalah jurnal yang sudah terindeks oleh lembaga pengindeks dunia, seperti Scopus, Science Citation Index (SCI), Social Science Citation Index (SSCI), Arts and Humanities Science Index (AHSI), ISI Thomson, Google Scholar, dan lain-lain.

Lembaga pengindeks dunia yang terkenal seperti Scopus mengklasifikasi jurnal internasional menjadi empat: Quartile 1 - Quartile 4 (Q1 - Q4). Secara umum Quartile jurnal dihitung dari jumlah total sitasi dalam satu tahun dibagi dengan jumlah dokumen jurnal itu dalam satu tahun. Semakin banyak yang mensitasi sebuah jurnal tentu akan semakin tinggi nilai Kuartilnya. Saat ini, peraturan kenaikan pangkat dosen di Indonesia mensyaratkan dosen publish di jurnal berkategori jurnal bereputasi ini.

\section{Fase Menulis}

Setelah melakukan beberapa kegiatan pada fase merencanakan manuskrip, seorang penulis bisa lanjut ke fase inti dari proses penulisan karya tulis ilmiah, yaitu fase menulis manuskrip itu sendiri. Pada tahap ini, peserta pelatihan diperkenalkan dengan struktur sebuah artikel jurnal. Sama halnya dengan tulang manusia sebagai pembentuk rangka badan, artikel ilmiah juga mempunyai 'tulang' untuk membentuk sebuah kerangka tulisan ilmiah. Jika salah satu dari bagian tersebut hilang, maka tidak akan terciptanya sebuah artikel ilmiah yang utuh dan sempurna. Adapun bagian-bagian inti dari sebuah karya ilmiah adalah: judul, abstrak, pendahuluan, metode, hasil dan pembahasan, dan kesimpulan.

Ketika membuat judul, seorang penulis perlu membuat judul yang 'eye catchy' atau yang menarik perhatian calon pembaca. Judul yang baik tidak boleh lebih dari lima belas kata kunci dari isi tulisan. Fungsi paling dasar dari sebuah judul adalah untuk menjelaskan isi dari karya ilmiah secara padat yang ringkas. Kata kunci yang menarik dalam judul membuat karya ilmiah seseorang berpotensi untuk diakses dan dibaca oleh khalayak yang lebih ramai.

Selanjutnya peserta pelatihan belajar bagaimana membuat abstrak yang baik. Abstrak adalah bagian terpenting yang menjadi sasaran utama pembaca dalam mencari literatur yang bersumber dari jurnal, karena abstrak menggambarkan secara umum mengenai penelitian mulai dari tujuan penelitian, metode, prinsip kerja, teori singkat, hasil, dan kesimpulan. Oleh karena itu, seorang penulis jurnal mesti pandai menulis abstrak secara singkat dan padat.

Setelah menulis abstrak, peserta pelatihan belajar bagaimana membuat pendahuluan jurnal. Bagian pendahuluan biasanya memuat sedikit latar mengapa topik yang sedang dibahas itu penting. Paragraf pertama harus memuat ringkasan yang singkat dari penelitian mutakhir sebelumnya. Hal ini harus berhubungan langsung dengan paragraf kedua yang merangkum apa yang peneliti lain sudah lakukan pada bidang ini, seperti apa saja batas-batas yang sudah ditemui dan apa saja pertanyaan-pertanyaan yang masih membutuhkan jawaban. Lalu, paragraf terakhir, harus dengan jelas menyatakan apa yang Anda lakukan dan alasannya (mengapa).

Kemudian, peserta pelatihan belajar tentang menulis bagian metodologi jurnal. Secara umum, metodologi mendeskripsikan bagaimana rancangan penelitian yang telah dilakukan dalam menjawab pertanyaan penelitian. Bagian ini termasuk mendeskripsikan desain penelitian, populasi dan sampel penelitian, metode 
pengumpulan data, teknik menganalisa data, dan hal lain yang terkait dengan aspek metodologis penelitian seperti lokasi dan waktu penelitian.

Setelah menulis bagian metodologi, peserta berlatih menuliskan bagian temuan dan pembahasan dalam sebuah jurnal ilmiah. Bagian ini adalah bagian terpenting dari karya ilmiah, karena fungsinya adalah untuk memberikan jawaban spesifik yang menjelaskan pertanyaan penelitian sebagaimana disebut pada bagian pendahuluan. Pada bagian ini, penulis bisa menggunakan teks, tabel, dan gambar yang menarik untuk menjelaskan temuan atas jawaban dari pertanyaan penelitian.

Setelah mendeskripsikan temuan, penulis perlu melakukan pembahasan. Bagian pembahasan pada artikel harus menyatakan lagi tujuan utama penelitian dan menjelaskan bagaimana temuan sesuai dengan ilmu pengetahuan yang sudah ada. Penulis juga perlu menjelaskan hal baru dari penelitiannya. Bandingkan dan kontraskan dengan studi lain di bidang yang sama. Selanjutnya, penulis perlu mengeksplorasi berbagai implikasi dari temuan itu untuk penelitian selanjutnya.

Bagian akhir dari isi manuskrip adalah kesimpulan. Maka, pelatihan ini juga mengajarkan bagaimana guru bisa membuat kesimpulan yang baik dari tulisan mereka. Beberapa yang mesti ada pada bagian simpulan adalah ringkasan umum dari hasil penelitian dengan menghubungkannya dengan pertanyaan penelitian. Kemudian perlu ditulis dengan ringkas apa implikasi dari hasil penelitian terhadap pengayaan bidang ilmu pengetahuan serta pastika ada 'take home message' yang bisa diambil pembaca dari tulisan.

Selain membahas bagian-bagian di atas, sesi workshop juga membahas dan melatih guru tentang bagaimana melakukan sitasi dan membuat referensi sesuai standar pengutipan dan referensi yang berlaku di dunia akademik. Peserta dilatih membuat kutipan langsung dan tidak langsung dengan mengikuti standar sitasi style populer seperti APA 6th Style, Harvard, IEEE, dan Turabian Style. Setelah mempelajari prinsip-prinsip beberapa jenis sitasi ini, peserta juga dilatih menggunakan aplikasi reference manager Mendeley untuk bisa melakukan semua itu secara otomatis.

\section{Pasca Penulisan}

Materi penutup dari workshop ini adalah tentang bagaimana guru bisa mensubmit draft artikel mereka secara online pada sistem Open Journal System dari jurnal yang sudah dituju. Pada bagian ini peserta dilatih bagaimana mengenal seluk beluk website jurnal, bagaimana membuat akun di OJS, bagaimana mengupload manuskrip, mengecek progress review di OJS, dan bagaimana mengumpulkan ulang manuskrip jika ada saran perbaikan dari reviewer.

Yang tak kalah penting pada fase ini adalah bagaimana seorang penulis bisa kuat menjalani proses review jurnal yang kadang lama. Dengan demikian, beberapa saran yang bersifat motivasi juga disampaikan di akhir sesi. Diantaranya adalah bagaimana seorang penulis memerlukan sikap mental persisten dalam proses menulis jurnal sampai jurnal itu terbit. Karena prosesnya bisa lama dan membutuhkan kesabaran dan perjuangan, hanya mereka yang persisten, pantang menyerah, yang akhirnya bisa berhasil publish di jurnal.

\section{Dampak Pelatihan}

Pada akhir sesi pelatihan, tim pengabdian menyebarkan angket untuk melihat dampak pelatihan ini pada peningkatan kemampuan guru. Karena kemampuan menulis tidak bisa langsung terlihat progressnya dalam waktu singkat, maka survey yang diberikan lebih melihat persepsi peserta pelatihan terkait peningkatan motivasi dan pemahaman mereka tentang seluk beluk penulisan jurnal ilmiah, sebagaimana tergambar pada grafik berikut: 


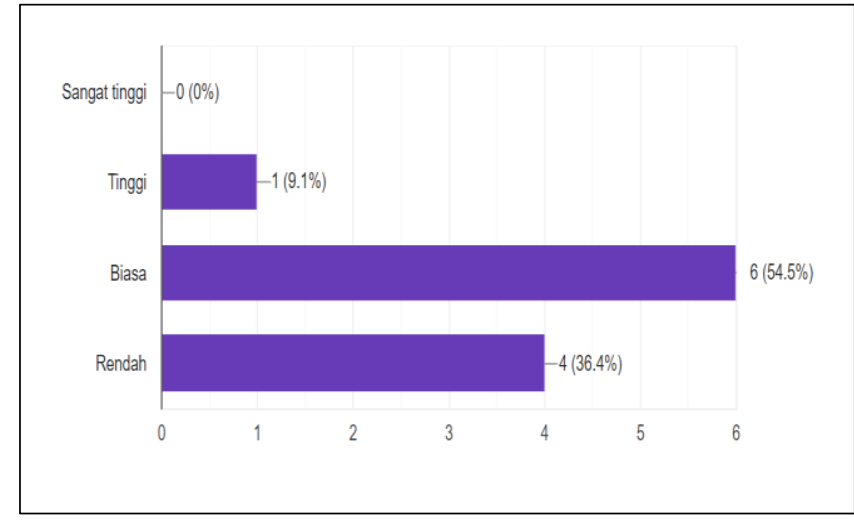

Sebelum

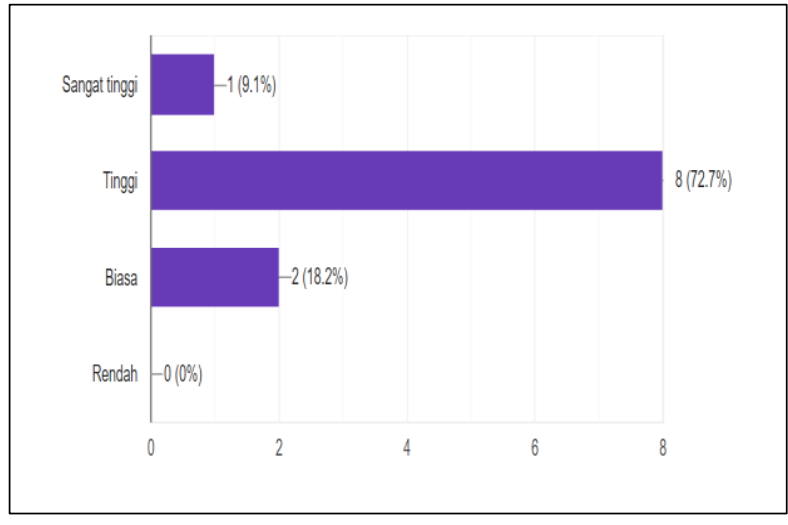

Setelah

Gambar 1: Motivasi Guru Untuk Menulis Jurnal Sebelum dan Setelah Pelatihan

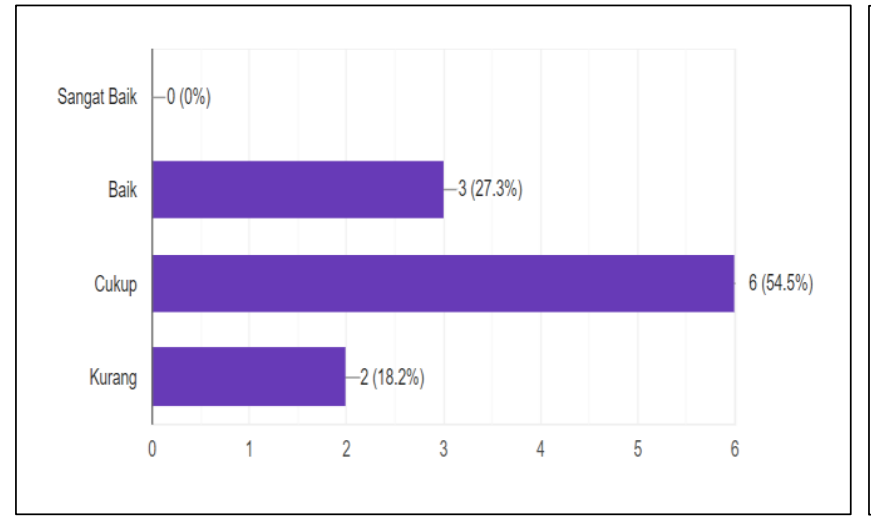

Sebelum

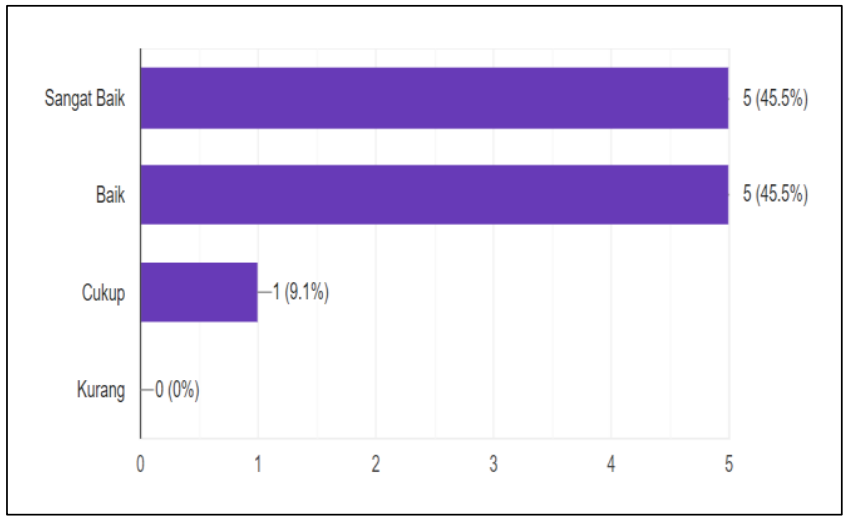

Setelah

Gambar 2: Pemahaman Guru Tentang Penulisan Jurnal Sebelum dan Setelah Pelatihan

Data dari Gambar 1 dan Gambar 2 menunjukkan bahwa secara umum pelatihan ini telah berdampak positif terhadap pengembagan kemampuan guru dalam menulis jurnal ilmiah. Hal ini bisa terlihat diantaranya dari data di atas. Sebelum pelatihan, $36.4 \%$ peserta menyatakan bahwa mereka memiliki motivasi yang rendah dalam menulis jurnal ilmiah. Hanya $9,1 \%$ yang memiliki motivasi tinggi. Setelah pelatihan, motivasi peserta tumbuh signifikan. Ada $72,7 \%$ peserta yang mengaku memiliki motivasi tinggi untuk menulis jurnal ilmiah.

Data terkait pertumbuhan pemahaman guru dalam teknis penulis jurnal ilmiah juga bergerak positif. Sebelum dilaksanakan pelatihan, mayoritas peserta pelatihan $(54.5 \%)$ mengaku hanya memiliki pemahaman cukup terkait seluk beluk penulisan jurnal. Setelah pelatihan, $45.5 \%$ peserta mengaku memiliki pemahaman baik. $45.5 \%$ lainnya bahkan mengaku memiliki pemahaman sangat baik. Dengan demikian, bisa disimpulkan bahwa pelatihan ini berhasil melakukan knowledge transfer kepada para guru peserta pelatihan.

\section{KESIMPULAN}

Konten pelatihan cukup padat mulai dari pengetahuan umum tentang dunia penulisan jurnal ilmiah sampai pada hal teknis bagaimana mensubmit jurnal ke sistem jurnal online. Pelatihan telah berjalan dengan cukup baik, walau ada kendala teknis seperti keterbatasan jumlah peserta luring karena mengikuti prosedur Covid. Meskipun begitu. pelatihan telah berdampak relatif baik, terutama dalam meningkatkan motivasi dan pemahaman guru terkait penulisan karya ilmiah (artikel jurnal). Kegiatan sejenis perlu terus dilakukan secara periodek dengan melibatkan lebih banyak guru. Kerjasama dengan komunitas guru seperti MGMP perlu diperbanyak. 


\section{UCAPAN TERIMAKASIH}

Ucapan terima kasih kami sampaikan kepada Bapak Rektor dan Ketua LPPM Universitas Riau yang telah memberikan bantuan dana kegiatan pengabdian kepada masyarakat di bawah skema Kegiatan Pengabdian Terintegrasi 2020 nomor kontrak 854/UN.19.5.1.3/PT.01.03/2020

\section{DAFTAR PUSTAKA}

Bunyamin. (2016). Teacher professionalism: A study on teacher's professional and pedagogic competence at vocational high schools in the Northern Coastal of Jakarta. Indonesian Journal of Educational Research, 2(1), 77-84.

Daud, A. (2007, December 14). Guru Sebagai Peneliti, Mungkinkah? Kompas.

Eko Putro Widoyoko. (2008). Penelitian Tindakan Kelas dan Pengembangan Profesi Guru. Disajikan dalam Seminar Nasional Peningkatan Kualitas Profesi Guru Melalui Penelitian Tindakan Kelas. Seminar Nasional Peningkatan Kualitas Profesi Guru Melalui Penelitian Tindakan Kelas. Jogjakarta.

Keraf, G. (1996). Terampil Berbahasa Indonesia. Jakarta: Balai Pustaka.

Marwan, A. (2017). The Assessment of English Teachers' Ability to Write A Scientific Article in English. Lingua Cultura, 11(2), 109. https://doi.org/10.21512/lc.v11i2.915

Nana Sudjana. (1987). Tuntunan Menyusun Karya Ilmiah. Bandung: Sinar Baru.

Palmer, P. J. (1999). The Courage to Teach. College Composition and Communication. https://doi.org/10.2307/35897

Zemach, D. E., \& Lisa A. Rumisek. (2005). Academic Writing: From Paragraph to Essay. Edumond. 